\title{
Species composition of green frogs (Pelophylax Esculentus Complex) of the Belgorod agglomeration based on DNA markers
}

\author{
Eduard Snegin ${ }^{1 *}$, Anatoliy Barkhatov ${ }^{1}$, Anton Sychev ${ }^{1}$, and Elena Snegina ${ }^{1}$ \\ ${ }^{1}$ Institute of Pharmacy, Chemistry and Biology, Belgorod State National Research University, Belgorod, Russia
}

\begin{abstract}
On the basis of molecular genetic analysis of the intron-1 of the nuclear serum albumin gene (SAI-1) were identified 177 individuals of Pelophylax esculentus complex of 9 localities Belgorod. Two types of population systems R and RE were identified. Pure populations of L-type, E-type and LE-type as well as P. lessonae individuals were not identified.
\end{abstract}

\section{Introduction}

The European green frogs complex (Pelophylax esculentus complex) includes three species: Pelophylax ridibundus (Pallas, 1771), P. lessonae (Camerano, 1882) and $P$. esculentus (Linnaeus, 1758) [1]. According to studies by a number of authors, hybrid frogs are distributed almost all over Europe; this fact may indicate their "evolutionary success". Hybrids and their parents often live together and form common breeding groups, despite differences in their lifestyle [2].

Accurate identification of species of the European green frogs complex is difficult, and hybrid species often erase the "boundaries" of parent species, but it is this necessary to solve a number of problems: ecological monitoring, study of species introduction and invasion and to develop a strategy for their conservation [3, 4]. More precise molecular genetic methods should be used to reliably identify the species belonging to Pelophylax esculentus complex $[2,3]$.

The aim of the study is a reliable species identification of the European green frogs Pelophylax esculentus complex in the Belgorod and its surroundings.

\section{Experimental}

The material was collected during the summer field season 2018-19. In total 177 individuals from 9 localities of Belgorod region were studied by molecular genetic method: 1. «Severskiy Donec» 50.591/36.608 ( $\mathrm{n}=14) ; 2$. «Vezelka» 50.601/36. $556 \quad(\mathrm{n}=17) ; 3$. «Oskochnoe» $50.647 / 36.557(\mathrm{n}=20)$; 4. «Jachnevskiy» 50.639/ 36.579 $(\mathrm{n}=16)$; 5. «Dubovoe» 50.533/ $36.583(\mathrm{n}=17)$; 6. «Ust'e» $50.530 / 36.649(\mathrm{n}=26)$; 7. «Maiskiy» 50.515/ 36.462 $(\mathrm{n}=19) ; \quad 8 . \quad$ «Severnyi» $50.733 \quad 36.487 \quad(\mathrm{n}=24) ; 9$. «Shopino» 50.705/36.611 ( $\mathrm{n}=24)$.

Molecular-genetic analysis was carried out Center of genomic selection of «Belgorod State National Research University».
The first phalanges of the hind leg were used as a tissue sample. To isolate genomic DNA, a set of DNA Extran-2 (Sintol) was used, according to the protocol proposed by the company. The obtained DNA solution was stored at $-20{ }^{\circ} \mathrm{C}$.

Determine hybrids and cryptic forms, the nuclear serum albumin gene (SAI-1) were used according to the developed PCR test of the Pelophylax esculentus complex identification system proposed by Ivanov A. Yu. and Ermakov O. A. [5].

DNA variability was analyzed using polymerase chain reaction method. Samples were prepared per tube before amplification as follows: $2.5 \mathrm{x}$ Reaction mixture $(2.5 \mathrm{x}$ PCR buffer B (KCl, TrisHCl (pH 8.8), $6.25 \mathrm{mM} \mathrm{MgCl}$ ), SynTaq DNA polymerase, deoxynucleoside triphosphates, glycerol, Tween 20 - $8 \mu \mathrm{l}$; MgCl2 $25 \mathrm{mM}$ $0.5 \mu \mathrm{l}$; deionized water $-9.3 \mu \mathrm{l}$, mix of primers $0.1 \mu \mathrm{l}$ (SA1F-Pu: CCATACAAATGTGCTAAGTAGGTT; SA1R-Pr: $\quad$ GATACAAATGATACATTCCCACCT; SA1R-PI: TACCGTACCGATATTTGTATGC; SA1R-Pb: TTGTTCCCTATACTAAGGTCAC).

PCR amplification was performed in the DNA amplifier Veriti (Thermo FS).

PCR amplification involved an initial cycle of denaturation at $95^{\circ} \mathrm{C}$ for $5 \mathrm{~min}$ and 35 subsequent cycles of $94{ }^{\circ} \mathrm{C}$ for $30 \mathrm{~s}, 60{ }^{\circ} \mathrm{C}$ for $60 \mathrm{~s}$, and $72{ }^{\circ} \mathrm{C}$ for $60 \mathrm{~s}$, followed by a final extension step at $72{ }^{\circ} \mathrm{C}$ for $10 \mathrm{~min}$.

After PCR, the amplification products were analyzed with electrophoresis in a $4 \%$ agarose gel followed by ethidium bromide staining and UV light imaging.

\section{Results and discussion}

Green frogs can form single-species "pure" (R, E and L) and mixed (RE, LE and REL) types of population systems. According to our study, 2 types of population systems - R and R-E types - have been identified in the Belgorod (Table 1).

*Corresponding author: snegin@bsu.edu.ru 
Table 1. Green frogs genotypes

\begin{tabular}{|c|c|c|c|c|c|c|c|}
\hline Population & $\mathrm{n}$ & $\mathrm{RR}$ & $\mathrm{BB}$ & $\mathrm{LL}$ & $\mathrm{BR}$ & $\mathrm{BL}$ & $\mathrm{LR}$ \\
\hline $\begin{array}{c}\text { «Severskiy } \\
\text { Donec» }\end{array}$ & 14 & 3 & 4 & 0 & 4 & 2 & 1 \\
\hline «Vezelka» & 17 & 5 & 7 & 0 & 5 & 0 & 0 \\
\hline «Oskochnoe» & 20 & 2 & 9 & 0 & 3 & 4 & 2 \\
\hline «Jachnevskiy» & 16 & 3 & 4 & 0 & 6 & 2 & 1 \\
\hline «Dubovo»» & 17 & 0 & 0 & 0 & 1 & 11 & 5 \\
\hline «Ust'e» & 26 & 1 & 2 & 0 & 4 & 12 & 7 \\
\hline «Maiskiy» & 19 & 3 & 3 & 0 & 8 & 3 & 2 \\
\hline «Severnyi» & 24 & 4 & 4 & 0 & 9 & 6 & 1 \\
\hline «Shopino» & 24 & 1 & 7 & 0 & 8 & 4 & 4 \\
\hline
\end{tabular}

Note: $\mathrm{n}$ - number of individuals; $\mathrm{R}$ - alleles of "western" form of marsh frog, B - alleles of "eastern" form marsh frog, L - alleles of pool frog.

The performed molecular genetic analysis revealed genetic heterogeneity of the green frog complex. Thus, on the urbanized territory of the Belgorod region, P. cf. bedriagae $(\mathrm{BB})$ and its hybrids $(\mathrm{BR}, \mathrm{BL})$ dominate in water bodies, being one of the invasive representatives of amphibians, has a negative impact on local batrochofauna [6].

Our studies confirm that $\mathrm{P}$. cf bedriagae is confined to urbanized landscapes. Pure populations of L-type, E-type, and LE-type, as well as P. lessonae individuals, were not detected.

The data obtained should be taken into account in ecological studies of the region's batrochofauna, since P. cf. bedriagae has a higher resistance to anthropogenic press than other representatives of the Pelophylax esculentus complex $[7,8,9]$.

\section{Conclusion}

As a result of the study, 2 species of green frogs complex were identified in the Belgorod agglomeration Pelophylax ridibundus and P. esculentus. The study of nuclear DNA showed that the lake frog has alleles of two cryptic forms - "western" (P. ridibundus) and "eastern" (P. cf. bedriagae). It was found that both forms of the lake frog participate in the formation of hybrid individuals (P. esculentus).

\section{References}

1. N.B. Ananyeva, L.Ya. Borkin, I.S. Darevskiy, N.L. Orlov. Amphibians and reptiles. Encyclopedia of Nature of Russia. (1998)

2. D.V. Dedukh, A.V. Krasikova, Genetics. 53. 885 (2017)

3. A.I. Faizulin, R.I. Zamaletdinov, S.N. Litvinchuk, L.Y. Rozanov, Y.M. Borkin, O.A. Ermakov, A.B. Ruchin, G.A. Lada, A.O. Svinin, I.V. Bashinsky, I.V. Chikhlyaev, Nature Conservation Research. Protected science. 1 (2018)

4. A.Yu. Ivanov. Proc. of Sci. Penza State University. Penza (2019)

5. O. Ermakov, A. Ivanov, S. Titov, A. Svinin, S.N. Litvinchuk, Russian Journal of Herpetology. 26, 367 (2019)

6. V.L. Vershininin, I.A. Sitnikov, S.D. Vershinina, A.G. Trofimov, A.A. Lebedinsky, I.I. Miura Genetics. 55, 972 (2019)

7. O.A. Ermakov, A.I. Faizulin, M.M. Zaks, Izv. Samarsk, center of RAS. 16, 409 (2014)

8. O.A Ermakov, M.M. Zaks, S.V. Titov, Vestnik Tambov. 18, 2999 (2013)

9. A. O. Svinin, A.Yu. Ivanov, M.M. Zaks, S.N. Litvinchuk, L.Ya. Borkin, Yu.M. Rozanov, O.A Ermakov, Modern herpetology. 15, 120 (2015) 